\title{
The Development of Writing Poetry Teaching Materials Based on Audiovisual Media of Fifth Grade Elementary School in Bone Regency
}

\author{
Rukayah \\ Universitas Negeri Makassar, Jln. Bonto Langkasa, Kampus Gunung Sari, Makassar, South Sulawesi, Indonesia \\ Achmad Tolla \\ Universitas Negeri Makassar, Jln. Bonto Langkasa, Kampus Gunung Sari, Makassar, South Sulawesi, Indonesia \\ Ramly \\ Universitas Negeri Makassar, Jln. Bonto Langkasa, Kampus Gunung Sari, Makassar, South Sulawesi, Indonesia
}

\begin{abstract}
The purpose of this research is to create the teaching material prototype which is valid, practical, and effective used in learning, especially in writing poetry of fifth grade elementary school in Bone regency. This study uses research and development method. The development model used is the Four-D models that include the definition (define), design, development (develop), and dissemination (disseminate). The design measures used in research and development $(R \& D)$ is pretest-posttest design. The data collection techniques used are observation, questionnaires, interviews, tests, and documentation. The finding data analyzed using descriptive and quantitative approach. The research results are: (1) the teaching material developed is writing poetry teaching materials based on audiovisual media with a video format that packaged in the form of compact disks (CD) which is divided into four videos, (2) writing poetry teaching material based on audiovisual media is stated valid. The average aspect of content or material is 3.30 with valid category. The mean of presentation aspect of teaching material is 3.60 with very feasible category. The average aspect of graph is 3.71 categorized as very feasible, and the mean aspect of language is 3.66 with very feasible category, (3) writing poetry teaching materials based on audiovisual media is practical to use in learning to write poetry by $5^{\text {th }}$ grade students in Bone regency. This is shown with a mean observation results of learning implementation at 4.57 categorized as very practical and the mean observation of learning management with an average of 4.54 categorized as very practical, (4) writing poetry teaching materials based on audiovisual media effectively used in learning. It is demonstrated by the response of teachers, students and students' test result. The mean response of four teachers is 3.88 with very good category. Furthermore, out of 80 students, 73 or $91.25 \%$ of them responded well or very well. The test results show that after the students learn to use the developed teaching materials, there is an increasing mastery learning of $71.43 \%$.
\end{abstract}

Index Terms—development, teaching materials, writing, poetry, audiovisual

\section{INTRODUCTION}

The effort to build the complete Indonesian man has become the government's determination since the Five-Year Development Plan I in 1969-1974. Ministry of National Education as a responsible of national education system determined to realize these lofty ideals. It is initiated by arranging a Strategic Plan of National Education Development. The Ministry of National Education's strategic plan becomes a guide for managers of all education levels, starting from the central government, local government, education unit, until the community in planning and implementing the national education development programs and evaluating the results.

Teachers as a main implementer of education in the country are expected to carry out their duties professionally. They need to constantly improve the professionalism, so that the noble ideals of the Indonesian nation which contained in Pancasila, the Constitution year of 1945, the Constitution No. 20 Year of 2003, and the Ministry of National Education's strategic plan can be realized.

Government Regulation No. 19 Year of 2005 Article 20 implies that teachers are expected to develop learning materials and reinforced through the Ministry of National Education's regulation. The fact that occurred in the field is the teachers rarely want to develop their own teaching material. The various reasons are: (1) a matter of time, because the material taught is very wide include various subject areas (Science, Social, Civics, Math, and Bahasa). These studies need devices such as: Lesson Plan, Student Worksheet, Media, and Assessment Tool. So, they do not have time to develop the material; (2) lack of confidence, because they feel their knowledge is still very limited; (3) they do not want to bother themselves. They assume that teaching materials has already provided commercially. They just choose which publisher will be used even though it is not necessarily can lead the students to achieve the goal. In other words, the 
available teaching materials on the market still require the adoption and adaptation before the instructional materials used by teachers.

Based on the analysis result of Bahasa teaching material including writing poetry teaching material that has been done by the author of various publishers in elementary school in the last five years, it is found that the conditions of the existing teaching materials still have weaknesses or deficiencies such as: (1) generally, the teaching materials exist from various publishers do not meet the systematic preparation of teaching materials; (2) the material is not presented in depth, for example: the poetry. The content is less described by the author, so students only see the typography poetry which is different from another writing; (3) the material is not easily digested by the students because generally the existing writing poetry teaching material only instruct students to write poetry example. The students are not guided to write poetry step by step; (4) the exposure of writing poetry material is less logically presented. The survey result conducted by Irawan (2014) shows that there are very few parties share videos of Bahasa teaching material, including writing poetry teaching material on the Youtube website. Besides, the physical quality and the content of video are less satisfying.

Teaching material is an important part in the implementation of learning in school. Through teaching materials, teachers will be easier to implement the learning and students will be more helpful and easier to learn. The advances in information technology, enabling the learning materials are not only stored in the textbook but also can be stored in various forms of technology that is more effective and efficient, for example: CDs, cassettes, videos, etc. These forms make the subject matter become more interesting to study. With a variety of animation techniques, the learning materials will be clearer and concrete.

Based on the phenomenon and the actual conditions in the field that has been described above, it conducted the research with the title "The Development of Writing Poetry Teaching Materials based on Audiovisual Media of Fifth Grade Elementary School in Bone Regency" with consideration that the effectiveness of a learning process is strongly influenced by the content or learning material which is interesting, inspiring, fun to challenge, and motivate the students to participate actively.

\section{A. Research Problem}

The problems of this research are:

1. What is the prototype of writing poetry teaching materials based on audiovisual media of fifth grade elementary school in Bone regency?

2. What is the feasibility of writing poetry teaching materials based on audiovisual media of fifth grade elementary school in Bone regency?

3. What is the practicality of writing poetry teaching materials based on audiovisual media of fifth grade elementary school in Bone regency?

4. How does the effectiveness of writing poetry teaching materials based on audiovisual media of fifth grade elementary school in Bone regency?

\section{B. Objective of the Research}

Based on the formulation of the problem that has been presented, this research aims:

1. to formulate the prototype of writing poetry teaching materials based on audiovisual media of fifth grade elementary school in Bone regency.

2. to produce the eligibility of writing poetry teaching materials based on audiovisual media for fifth grade elementary school in Bone regency.

3. to produce the practicality of writing poetry teaching materials based on audiovisual media for fifth grade elementary school in Bone regency.

4. to produce the effectiveness of writing poetry teaching materials based on audiovisual media for fifth grade elementary school in Bone regency.

\section{Significance of the Research}

The significance obtained in this study are: (1) to contribute the ideas on the development of theories in learning Bahasa and literature, especially in the design of writing poetry teaching materials based on audiovisual media (2) to help the ongoing activities of the learning to become more interesting and fun, also it can make the students more enthusiastic in learning, so the mastery concepts about writing poetry is more increased, (3) the development of writing poetry teaching materials based on audiovisual media can help teachers to facilitate the learning process and clarify the learning materials especially, writing poetry.

\section{LITERATURE REVIEW}

\section{A. Definition of Development}

The development is one of the research methods used to produce a particular product, and test the effectiveness of these products. (Sugiyono, 2012) Teaching materials is a set of materials/substances teaching materials that are arranged systematically, showing the whole figure of the competencies which students will learn in learning activities. The basis 
consist of the knowledge, values, attitudes, actions, and skills that contains the message, information, and illustrations in the form of facts, concepts, principles, and processes related to the subject of a specific language which aimed to achieve the learning objectives (Suryaman, 2014).

\section{B. Teaching Material Theory}

Teaching materials is a set of materials/substances (teaching materials) that are arranged systematically, showing the figure of the whole of the competencies which students will learn in learning activities. (Ministry of National Education, 2008) It can be concluded that teaching materials are all kinds of materials used to help the teachers/instructors in carrying out the teaching and learning activities. The material can be written or unwritten.

\section{Definition of Writing}

Writing is a form of manifestation abilities or language skills for learners to be mastered most recently after listening, speaking, and reading ability. The writing ability requires mastery of the various elements of language and elements outside the language itself that will be a content of paragraph, both language elements and the content elements should be tied neatly to produce a coherent and cohesive paragraph. (Nurgiantoro 2010) It is concluded that writing is a form of indirect communication to convey the idea of the writer to the reader by using language media. Both elements of the language and content of the element should be neatly interwoven.

\section{Definition of Poetry}

Etymologically, the term poetry comes from the Greek poeima 'create' or poeisis 'manufacture' and in English is called poem or poetry. Poetry means 'make' and 'making of' because through poetry, someone has created a world of their own that may contain a message or picture of a certain atmosphere both physically and mentally. (Aminuddin, 2006)

\section{E. Definition of Audiovisual Media}

Audiovisual media is a media that has an element of sound and image. This type of media has the better ability because it includes both types of media auditory (hearing) and visual (seeing). (Arsyad, 2010) Thus, it can be said that the media is a component of a learning resource or physical vehicle containing instructional materials in the student environment that can stimulate students to learn. In other word, the media is a tangible object that used to facilitate the learning process, so the material being taught is more easily understood by students.

\section{RESEARCH METHODS}

This study is research and development method. This study is conducted at elementary school in Bone regency, spread in three locations namely: SD Negeri 13 Biru, SD Negeri 24 Macanang, and SD Inpres10/73 Maroanging

The research instruments used in this study are: (1) the validation sheet of teaching material; (2) the observation sheet of students' activity; (3) the response's questionnaire of student and teacher; (4) test to measure the ability in writing poetry of fifth grade elementary school that used as a data source.

The data collection techniques used in this study include: (1) the interview to find out more about the motivations, characteristics, conditions of the students and teachers, (2) observation used to collect data about the activity and creativity of students and teacher's activity, (3) test used to collect data on the ability of the initial (test pilot small groups) and the final ability of student in writing poetry (trial field test or real), and (4) questionnaire used to determine the level of model effectiveness and teaching materials as well as to determine the student's motivation for ongoing learning.

The study design refers to the 4D model (four D) developed by S. Thiagarajan, Dorothy S., Semmel, and Melvyn I. Semmel. The stages of development model 4D is the definition (define), design (design), development (develop), and deployment (dissemninate).

The data that had been collected using instruments then analyzed quantitatively and directed to determine the validity, practicality, and effectiveness of interactive multimedia that has been developed. The techniques used are:

1. The data analysis prototype of teaching materials

The Data analysis techniques prototype of teaching materials is an analysis qualitative with descriptive approach that presents the data in a narrative form.

2. The analysis of feasibility data used inter-validator deal models

\begin{tabular}{|l|l|}
\hline$A$ & $B$ \\
\hline$C$ & $D$ \\
\hline
\end{tabular}

Notation:

A = Weak Validity, if both experts' assessment worth 1 or 2

$\mathrm{B}=$ Weak Validity, if the second expert assessment worth 3 or 4

$\mathrm{C}=$ Weak Validity, if the first expert assessment worth 1 or 2 and the second expert assessment worth 3 or 4

$\mathrm{D}=$ Strong Validity, if both experts' assessment worth 3 or 4 
The formula of mean result validator assessment for each criterion is:

Content Validity $=\frac{D}{(A-B-C-D)}$

To determine the appropriateness or not, it uses Ruslan validation (2009). If the coefficient validity is low $(<75 \%)$, then the votes considered invalid. If the validity coefficient is high ( $75 \%$ upwards), then the votes considered valid.

3. Data analysis practicality

According Trianto (2009: 25), practicality aspect can only be met if: (1) experts and practitioners state that what is developed can be applied, (2) the fact shows that what is developed can be applied. The activities undertaken in the data analysis process of implementation learning device and management learning are as follows:

a. Looking for a mean total $(\bar{x})$ with the formula:

$$
\bar{x}=\frac{\sum_{i=1}^{n} A_{t}}{n}
$$

Notation:

$\bar{x}$ : mean total

$\bar{A}_{t}:$ mean aspects of $(-\mathrm{i})$

$\mathrm{n}$ : number of aspects

b. To determine the implementation category of each aspect or all of the aspects to match the mean of each $\bar{A}_{t}$ or mean total ${ }^{\bar{x}}$ with predefined categories;

c. The implementation category of each aspect or all aspects of the implementation device cited by Nurdin (2007) are as follows:

$1.5 \leq \mathrm{M} \leq 2$ entirely implemented

$0.5 \leq \mathrm{M} \leq 1.5$ partially implemented

$0.0 \leq \mathrm{M} \leq 0.5$ not implemented

Notation:

$\mathrm{M}=\bar{A}_{t}$ to find the implementation of each aspect

$\mathrm{M}={ }^{\bar{x}}$ to find the implementation of all aspects

$\mathrm{M} \sim 4$ to find the implementation of each aspect

The criteria used to decide the learning device has a sufficient degree of implementation is the value of $X$ and $A$, minimum in the partially implemented category. If the value of $M$ is in the other categories, it should be revised by looking at the aspects that has less value.

4. The effectiveness of data analysis

a. The effectiveness analysis of audiovisual media

The effectiveness analysis of audiovisual media is supported by the results data analysis of effectiveness components namely learning outcomes test. The activity of data analysis components are as follows:

a) The effectiveness analysis of audiovisual media by limited trial group.

To obtain the result data of limited trial student learning test, firstly, identify the students who have not been able to write poetry well of each class. Before applying audiovisual media, the pre-test is done to determine the ability of beginning students. After being given the treatment in the learning process with the use of audiovisual media in the limited trial group, then it held posttest to determine the final ability of limited trial group. The study design used one group pretest-posttest like in the following figure:

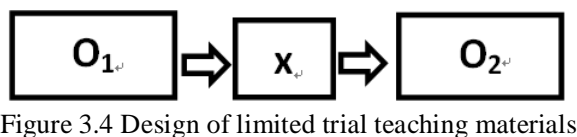

Notation:

$\mathrm{O} 1=$ initial ability of students

$\mathrm{O} 2=$ final capabilities

$\mathrm{x}=$ treatment

b) The analysis of the students' ability test to write poetry on implementation broader test

The result data of student learning test in the implementation broader test group is done by comparing the situation before and after use (before-after). The experiment model used the same model as limited trial classroom.

The result data of writing poetry ability analyzed by determine the scores and final scores of each student. Furthermore, the value is accumulated classically and the average determined. The Value Minimum Completeness (VMC) is 70. It means that students are stated able to write poetry if they obtain a final value at least 70. In other word, students are stated able to write poetry if there is an increasing learning outcome at least $50 \%$.

c) Analysis of the response of teachers and students

The calculation result of teacher and student's response in learning to write poetry using audiovisual media obtained from the actual score and ideal score of the respondents' tabulation. The actual score obtained through the calculation 
results throughout the opinions of respondents according to the classification that has been given. The ideal scores obtained from the highest value acquisition multiplied by the number of questionnaires multiplied by the number of respondents. The formula used is:

Actual Score $=\frac{\text { Actual Score }}{\text { Ideal Score }} \times 100 \%$

The criteria for the percentage of respondents can be seen in the table below:

TABLE 1.

CRITERIA PERCENTAGE OF RESPONDENTS

\begin{tabular}{lll}
\hline No & \% Total Score & Criteria \\
\hline 1 & $20,00 \%-36,00 \%$ & Very Low \\
2 & $36,01 \%-52,00 \%$ & Less / Low \\
3 & $52,01 \%-68,00 \%$ & Enough / Medium \\
4 & $68,01 \%-84,00 \%$ & Good / High \\
5 & $84,01 \%-100 \%$ & Very High \\
\hline
\end{tabular}

\section{RESULTS AND DisCUSSION}

A. The Prototype of Writing Poetry Teaching Materials Based on Audiovisual Media of Fifth Grade Elementary School in Bone Regency

Writing poetry teaching materials based on audiovisual media using 4-D model, namely: defining, designing, development, and dissemination.

a. The results of the definition (define) include: analysis of the curriculum, the analysis of teachers' need, the analysis of students' need, media selection of teaching materials, and the selection format of teaching materials.

b. The results of design. Writing poetry teaching materials designed into four videos.

c. The results of development (develop). The development of writing poetry teaching materials using some sophisticated electronic device with the purpose of producing teaching material (video) quality. The devices are: Canon EOS 7D Camera, Lighting, Sound Recorder, Microphone or Clip On, Computer and Software Editing.

d. Dissemination is done through: workshop of teaching materials development, one-day seminar, international scientific journal publications Scopus index, the publication of textbooks for the future elementary school teachers, teaching materials posted on several online based account.

B. The Feasibility of Writing Poetry Teaching Materials Based on Audiovisual Media of Fifth Grade Elementary School in Bone Regency

a. The results of mean validation, syllabus, lesson plan, student worksheets of validator I and II

TABLE 2.

RESULTS OF MEAN VALIDATION, SYLLABUS, LESSON PLAN, STUDENT WORKSHEETS OF VALIDATOR I AND II FROM BOTH VALIDATOR

\begin{tabular}{|c|c|c|c|c|}
\hline \multirow{2}{*}{ No } & \multirow{2}{*}{ Aspect } & \multicolumn{2}{|c|}{ Validator } & \multirow{2}{*}{ Notation } \\
\hline & & I & II & \\
\hline 1. & Syllabus & 4,00 & 4,39 & valid \\
\hline 2. & Lesson Plan & 4,00 & 4,27 & valid \\
\hline 3. & Student Worksheet & 3,90 & 4,45 & valid \\
\hline
\end{tabular}

Table 2 shows that the results of the validation of the validator I and II can be concluded that the instruments supporting teaching material aspects of the syllabus, lesson plans, and student worksheets have met the validity requirements to be used as a writing poetry teaching material based on audiovisual media of fifth grade elementary school

b. The mean validation results of writing poetry teaching material based on audiovisual media from the aspect of feasibility content and feasibility presentation

TABLE 3.

THE MEAN VALIDATION RESULTS OF WRITING POETRY TEACHING MATERIAL BASED ON AUDIOVISUAL MEDIA FROM THE ASPECT OF FEASIBILITY CONTENT AND FEASIBILITY PRESENTATION

\begin{tabular}{|l|l|l|l|l|}
\hline \multirow{2}{*}{ No } & \multirow{2}{*}{ Aspect } & \multicolumn{2}{|c|}{ Validator } & \multirow{2}{*}{ Notation } \\
\cline { 3 - 4 } & & I & II & \\
\hline 1. & Content Validation & 3.04 & 3.35 & Valid \\
\hline 2. & Presentation Validation & 3.81 & 3.50 & Valid \\
\hline
\end{tabular}

Table 3 shows the validation results of teaching materials assessed from the material aspects by two validators. The aspects assesses are feasibility content and presentation. The assessment of both validators is on valid category.

c. The mean validation results of writing poetry teaching materials media from graph and linguistics aspects 
TABLE 4.

THE MEAN VALIDATION RESULTS OF WRITING POETRY TEACHING MATERIALS MEDIA FROM GRAPH AND LINGUISTICS ASPECTS

\begin{tabular}{|l|l|l|}
\hline \multirow{2}{*}{ Step } & Aspect & Language \\
\cline { 2 - 3 } & Graph & 2.89 (not valid) \\
\hline I & 2.80 (not valid) & 3.70 (valid) \\
\hline II & 3.23 (valid but still need revision) & - \\
\hline III & 3.45 (valid, need a little bit revision) & \\
\hline
\end{tabular}

Table 4 shows the validation results of teaching materials by media aspects from two validators. The validation media aspect is done in three stages for graph aspect because the first and the second phase have not received feasibility recommendations from the validator. The validation of linguistics aspect is done twice. The assessment of both validators is in eligible to use category.

\section{The Practicality of Writing Poetry Teaching Materials Based on Audiovisual Media}

\section{a. The mean observation result of learning implementation}

TABLE 5.

THE MEAN OBSERVATION RESULT OF LEARNING IMPLEMENTATION

\begin{tabular}{|c|c|c|c|c|}
\hline \multirow{2}{*}{ No } & \multirow{2}{*}{ School } & \multicolumn{3}{|l|}{ Meeting } \\
\hline & & I & II & III \\
\hline 1. & $\begin{array}{l}\text { SDN } 13 \text { Biru Class A } \\
\text { (Limited Trial) }\end{array}$ & $\begin{array}{ll}4.00 & 3.00\end{array}$ & $4.60 \quad 3.80$ & $5.00 \quad 4.80$ \\
\hline 2. & $\begin{array}{l}\text { SDN } 13 \text { Biru Class B } \\
\text { (First Trial ) }\end{array}$ & $4.00 \quad 4.00$ & $4.80 \quad 4.60$ & $\begin{array}{ll}5.00 & 5.00\end{array}$ \\
\hline 3. & $\begin{array}{l}\text { SDN } 24 \text { Macanang } \\
\text { (Second Trial) }\end{array}$ & $\begin{array}{ll}5.00 & 5.00\end{array}$ & $5.00 \quad 5.00$ & $\begin{array}{ll}5.00 & 5.00\end{array}$ \\
\hline 4. & $\begin{array}{l}\text { SD Inpres 10/73 Maroanging } \\
\text { (Third Trial) }\end{array}$ & $4.00 \quad 4.00$ & $4.40 \quad 4.20$ & $4.80 \quad 4.80$ \\
\hline
\end{tabular}

The learning implementation is used to measure the practicality of the developed teaching materials. This data is obtained through the observation made by the two observers during the ongoing learning. The learning activities carry out by three times face to face. The observation result data of two observers on four classes in three schools shows the final mean of learning implementation categorized as very practical.

\section{b. The mean result of learning management response}

TABLE 6.

THE MEAN RESULT OF LEARNING MANAGEMENT OF THREE TIMES MEETING

\begin{tabular}{|c|c|c|c|c|c|c|c|}
\hline \multirow{2}{*}{ No } & \multirow{2}{*}{ School } & \multicolumn{6}{|c|}{ Meeting } \\
\hline & & I & & II & & III & \\
\hline 1. & $\begin{array}{l}\text { SDN } 13 \text { Biru Class A } \\
\text { (Limited Trial) }\end{array}$ & 3.80 & 3.70 & 4.50 & 4.70 & 4.80 & 5.00 \\
\hline 2. & $\begin{array}{l}\text { SDN } 13 \text { Biru Class B } \\
\text { (First Trial) }\end{array}$ & 4.30 & 3.80 & 4.80 & 4.50 & 5.00 & 5.00 \\
\hline 3. & $\begin{array}{l}\text { SDN 24 Macanang } \\
\text { (Second Trial) }\end{array}$ & 5.00 & 5.00 & 5.00 & 5.00 & 5.00 & 5.00 \\
\hline 4. & $\begin{array}{l}\text { SD Inpres 10/73 Maroanging } \\
\text { (Third Trial) }\end{array}$ & 3.80 & 4.10 & 4.00 & 3.70 & 4.70 & 4.70 \\
\hline
\end{tabular}

Learning management used to measure the practicality of teaching materials. This data is obtained through observation by two observers. The observation of learning management is conducted three times. The observation result shows the learning management using writing poetry teaching material based on audiovisual media is in very good category. The final mean of learning management of the four classes in three schools are in the very practical category.

D. The Effectiveness of Writing Poetry Teaching Materials Based on Audiovisual Media for Fifth Grade Elementary School in Bone Regency

a. The mean result of teacher model response's questionnaire

TABLE 7.

THE MEAN RESULT OF TEACHER MODEL RESPONSE'S QUESTIONNAIRE

\begin{tabular}{|l|l|l|l|}
\hline No. & Identity & Mean Result & Category \\
\hline 1. & Teacher Model I & 3.90 & Very Good \\
\hline 2. & Teacher Model II & 3.70 & Very Good \\
\hline 3. & Teacher Model III & 3.90 & Very Good \\
\hline 4. & Teacher Model IV & 4.00 & Very Good \\
\hline
\end{tabular}

Table 7 shows the response of four teachers' model on the developed teaching materials teaching. It is stated that writing poetry teaching material is practical to use. 
TABLE 8.

THE DISTRIBUTION OF TEACHER RESPONSES' QUESTIONNAIRE

\begin{tabular}{|c|c|c|c|c|c|c|c|c|c|c|c|}
\hline \multirow{2}{*}{ No. } & \multirow{2}{*}{ School } & \multicolumn{4}{|c|}{ Score } & \multicolumn{4}{|c|}{ Category } & \multirow{2}{*}{$\begin{array}{l}\text { Frequenc } \\
\mathbf{y}\end{array}$} & \multirow{2}{*}{ Percentage } \\
\hline & & 1 & 2 & 3 & 4 & SB & B & KB & TB & & \\
\hline 1 & $\begin{array}{l}\text { SDN } 13 \text { Biru Class A } \\
\text { (Limited Trial) }\end{array}$ & $\checkmark$ & $\checkmark$ & $\checkmark$ & $\checkmark$ & $\checkmark$ & $\checkmark$ & $\checkmark$ & $\checkmark$ & $\begin{array}{l}1 \\
10 \\
4 \\
0\end{array}$ & $\begin{array}{l}6.7 \\
66.7 \\
26.6 \\
0\end{array}$ \\
\hline 2 & $\begin{array}{l}\text { SDN } 13 \text { Biru Class B } \\
\text { (First Trial) }\end{array}$ & $\checkmark$ & $\checkmark$ & $\checkmark$ & $\checkmark$ & $\checkmark$ & $\checkmark$ & $\checkmark$ & $\checkmark$ & $\begin{array}{l}2 \\
28 \\
0 \\
0\end{array}$ & $\begin{array}{l}6.7 \\
93.3 \\
0 \\
0\end{array}$ \\
\hline 3 & $\begin{array}{l}\text { SDN } 24 \text { Macanang } \\
\text { (Second Trial) }\end{array}$ & $\checkmark$ & $\checkmark$ & $\checkmark$ & $\checkmark$ & $\checkmark$ & $\checkmark$ & $\checkmark$ & $\checkmark$ & $\begin{array}{l}0 \\
21 \\
3 \\
0\end{array}$ & $\begin{array}{l}0 \\
87.5 \\
12.5 \\
0\end{array}$ \\
\hline 4 & $\begin{array}{l}\text { SD Inpres 10/73 Maroanging } \\
\text { (Third Trial) }\end{array}$ & $\checkmark$ & $\checkmark$ & $\checkmark$ & $\bar{\checkmark}$ & $\bar{\checkmark}$ & $\checkmark$ & $\checkmark$ & $\checkmark$ & $\begin{array}{l}4 \\
7 \\
0 \\
0\end{array}$ & $\begin{array}{l}36.4 \\
63.6 \\
0 \\
0\end{array}$ \\
\hline
\end{tabular}

Table 8 shows the data distribution of student's questionnaire. Out of the four classes of respondents (80 students), there are 7 students $(8.75 \%)$ give very good response, there are 66 students $(82.5 \%)$ respond well, there are 7 students $(8.75 \%)$ respond poorly, and there is no student who gives not good response. The responses of 80 students show that the teaching material is practical to use.

\section{E. The Results Data of Respondents' Pretest and Posttest}

\begin{tabular}{|l|l|l|l|l|l|}
\hline \multirow{2}{*}{ No. } & \multirow{2}{*}{ School } & Pretest & \multicolumn{2}{l|}{ Posttest } \\
\cline { 3 - 6 } & & Complete (\%) & Incomplete (\%) & Complete (\%) & Incomplete (\%) \\
\hline 1. & $\begin{array}{l}\text { SDN 13 Biru Class A } \\
(\text { Limited Trial) }\end{array}$ & $5(38 \%)$ & $10(67 \%)$ & $15(100 \%)$ & $0 \quad(0 \%)$ \\
\hline 2. & $\begin{array}{l}\text { SDN 13 Biru Class B } \\
(\text { First Trial) }\end{array}$ & $9(30 \%)$ & $21(70 \%)$ & $26(86.6 \%)$ & $4(13 \%)$ \\
\hline 3. & $\begin{array}{l}\text { SDN 24 Macanang } \\
\text { (Second Trial) }\end{array}$ & $17(71 \%)$ & $7(29 \%)$ & $22(92 \%)$ & $2(8 \%)$ \\
\hline 4. & $\begin{array}{l}\text { SD Inpres 10/73 Maroanging } \\
\text { (Third Trial) }\end{array}$ & $6(55 \%)$ & $5 \quad(45 \%)$ & $11(100 \%)$ & $0 \quad(5 \%)$ \\
\hline
\end{tabular}

Table 9 shows the pretest and posttest result in writing poetry of fifth grade students at Bone regency. The pretest result of 80 students in four classes at the three schools state that there are 37 students get incomplete score and there are 43 students get complete score. After being given treatment of 80 students, there are 74 students who get complete score and there are 6 students who get incomplete score. From these results, it can be concluded that there is an increasing in student learning outcomes significantly. This shows that writing poetry teaching material based on audiovisual media is effectively to improve the learning outcomes of fifth grade student.

\section{F. The Discussion of Research Result}

One of the most important parts of the educational curriculum is a source of learning. Therefore, the substance of learning resources itself must be preserved and developed its quality. In this regard, the teacher has a strategic role to continue to do the innovation in the development of learning resources. One of them is through the development of teaching materials.

Based on the curriculum analysis, there are several weaknesses in the teaching materials that being used. The weaknesses include: (a) some basic competence (BC) are not deeply extract the outer element that will be achieved, for example at $\mathrm{BC}$ : 8.1 writing poems with attention to the theme and rhyme, $\mathrm{BC}$ : 8.2 writing poems with attention to diction and style of language. In these basic competencies, the element overlooked is the 'theme' in a poem, (b) balancing or the balance between material, examples, and performance in teaching materials have not been met, (c) the media teaching materials used in elementary school, especially in Bone regency still limited to instructional print materials, while the development of information and technology (IT) become a demand for actors who are struggling in the world of education to continue in adapting and applying these technologies in the curriculum system.

Based on these problems, the development of teaching materials especially at BC 8.1 and 8.2 is the answer from the demands of the Educational Unit Level Curriculum (EULC) namely creating the curriculum that facilitates learners to learn and understand the content or subject matter. This teaching material is extract deeply and specific about basic competence (BC) and objectives that will be achieved by focusing on the suitability and the balancing between material, examples, and performance. Thus, the learning process will be more systematic.

The selection of audiovisual media is intended as an optimization of students learning effort by mixing and matching the visual aspects (sight) and audio aspects (hearing) into heard-view media (audiovisual). These media are very 
effective to use in learning to write, especially for fifth grade students of elementary school. At this age, students are more interested in learning a dynamic media or media that can involve two main senses namely eyes and ears. This is relevant with Sudjana and Rival (2003: 58) state that the audiovisual media is the amount of equipment used by teachers to convey the concepts, ideas and experiences captured by the sense of viewing and hearing. Media of this type effectively used to improve students' writing skills. Irlidiyah also states that the use of technology based learning is greatly needed in today's era. Technology has an advantage of other media.

\section{CLOSING}

\section{A. Conclusion}

The developed teaching material is writing poetry teaching materials based on audiovisual media with a video format that packaged in the form of compact disks (CD) which is divided into four videos. The first video is more emphasis on the discussion of: (a) the definition of poetry and free-verse poetry, (b) the differences between poetry and another kind of writing, (c) the steps of writing good poetry, (d) the elements of poetry's builder and 'theme'. The second video emphasizes the mandate or purpose and rhyme in the poetry and also the examples of its application in writing poetry. The third video emphasizes on diction and style of language in poetry and the examples of its application in writing poetry. The fourth video is focused on evaluation.

Writing poetry teaching materials based on audiovisual media is stated valid or feasible to use. The mean ratings of two validators on aspects of teaching materials are 3.30 with good categories. The material assessment of two validators to the teaching materials of presentation aspects are 3.66 with very good category. The mean score assessment of teaching material to the graph aspects is 3.71 with very good category. The mean score on aspect of linguistic teaching material is 3.66 with very good category. From these results, it is concluded that writing poetry teaching materials based on audiovisual media is declared invalid.

Writing poetry teaching materials based on audiovisual media is practical to be applied in teaching. Class A (limited trial) obtained good results with mean score of 4.27. While in class B (field tests), the mean score is 4.63 with very good category. The implementation of teaching materials in SDN 24 Macanang obtains mean score of 5.00 with a very good category. The implementation of teaching materials in SD Inpres 10/73 Moroanging obtains mean score of 4.37 with good category. The mean score of the implementation teaching material in four trials classes is 4.57 with very good category. It is concluded that writing poetry teaching materials based on audiovisual media is practical to be implemented.

Based on the result test after treatment, it can be concluded that the four classes both trials limited test and field trials of three schools obtain maximum results. There is an increasing of student's learning outcome at the top of the standards that have been set (minimum 50\%), which proves that writing poetry teaching materials based on audiovisual media effectively improve the student's learning outcome.

\section{B. Suggestion}

Based on these findings, it is proposed the following suggestions:

1. It is expected for elementary school teachers to implement the writing poetry teaching materials based on audiovisual media, because it is proven to improve the student's learning outcome in writing poetry.

2. The Institute for Education Quality Assurance (IEQA) should pay attention to the teachers in the form of training, seminars, and workshops on the development of teaching materials such as video in order to improve their professionalism, so that the product of video teaching materials is more increase.

3. It is expected for Ministry of Education recommends the teaching materials that have been developed to use in elementary schools, especially in the fifth grade because it has been through the test phase with effective results, and in accordance with the applicable curriculum;

4. For the next researcher, to develop teaching materials based on audiovisual media and find new strategies on aspects of other language skills such as listening, speaking, reading or writing on another theme with varied models so that the quality of the content and the physical quality of the video is more satisfying and interesting.

\section{REFERENCES}

[1] Aminuddin. (2006). Pengantar Apresiasi Karya sastra. Bandung: Sinar Baru

[2] Arsyad, Azhar. (2010). Media Pembelajaran. Jakarta: Rajawali Press.

[3] Depdiknas. (2008). Panduan Pengembangan Bahan Ajar. Jakarta: Depdiknas.

[4] Hairston, Maxine C. (1981). Successful Writing. New York London: W.Norton7 Co.

[5] Irawan, Yusuf. (2014). Keterbatasan Video Pembelajaran Bahasa Indonesia di Media Youtube (Sebuah Tantangan Pemartabatan Bahasa Indonesia) Dalam Ansari, Azis, dan Usman (Eds.) Prosiding Simposium Internasional Bahasa, Sastra, \& Budaya Indonesia dalam Pengembangan Profesionalisme (p. 429-432). Makassar: UNM Makassar.

[6] Irlidiya. (2015). "Pengembangan Bahan Ajar Membaca Permulaan Berbasis Multimedia Interaktif Di Sekolah Dasar". Disertasi. Makassar. Program Pascasarjana. Universitas Negeri Makasaar.

[7] Narimawati, Umi. (2008). Metodologi Penelitian Kualitatif dan Kuantitatif, Teori dan Aplikasi. Bandung: Agung Media.

[8] Nurgiyantoro, Burhan. (2010). Penilaian dalam Pengajaran Bahasa dan Sastra. Yogyakarta: UGM Press.

[9] Semi, M. Atar. (2002). Dasar-Dasar Keterampilan Menulis. Bandung: Angkasa. 
[10] Sugiyono. (2012). Metode Penelitian Pendidikan (Pendekatan Kuantitatif, Kualitatif, dan R\&D). Bandung: Alfabeta.

[11] Suryaman, Maman. (2014). Workshop penulisan Bahan Ajar Modul (Online), http://www.uny.ac.id/?q=.html, (accessed 22 Desember 2015).

[12] Thiagarajan, Sivasailam, dkk. (1974). Instructional Development for Training Teachers of Exceptional Children. A Source ebook. Bloomington Indiana: Central for Innovation onthe Handicapped.

[13] Wang, Qiyun, \& Cheung W.Sun. (2003). Designing Hypermedia Learning Enviroment. Singapore: Pearson Education Asia Pte. Ltd.

Rukayah was born in Pattirobajo Bone Regency 27 July 1962 from h. Andi Badjid and Hj. Andi Mulekana. The author completed the undergraduate education at the Faculty of Arts in IKIP Ujung Pandang year 1986. The year 1999 the author continued his studies to postgraduate program S2 of UNM, and Language education courses completed in 2001. Year 2012 writers continuing education to postgraduate program S3 of UNM, language and education courses completed in 2016.

The author initiated his career as a teacher of SPG Negeri Parepare. Year 1987-1991, The author was appointed as a Tutor Program Area D - II PGSD organized by the Directorate of primary education, in cooperation with the Directorate General of higher education through PBJJ. Year 1991, the author was integrated as an educational effort to IKIP Ujung Pandang, now named UNM. In addition to duty at UNM authors as outstanding lecturer at several colleges of which Muhammadiyah STIKIP Bone 2001-2008 year, STAI AL-Ghazzali Bone, in 2004-2009, and as a Tutor at the Universitas Terbuka of the year 2008-20014.

Achmad Tolla, was born on March 21, 1949 in Leling-Mamuju, Indonesia. He is a lecturer at the Faculty of Languages and literature at State University of Makassar. He graduated in elementary school in Mamuju in 1965. He graduated Junior High School in Mamuju in 1968. And then he continued his Senior high School in Mamuju and graduated in 1970, Bachelor's degree (S1) in Education of language and Literature of IKIP Ujung Ppandang in 1980, Master (S2) in Indonesian Language Education, post graduate IKIP Malang in 1991, and Postgraduate Degree (S3) in Indonesian Language Education, UM Malang in 1996.

Achmad Tolla, has some scientific publications, namely: (1) Shifting of languages as the result of a merging of different ethnic, in 2007, (2) Language shift in environmental migrants in Luwuk, 2004, and (3) The development of communicative language Indonesia test device for primary school Pupils in the city of Makassar, in 2003. He has been the Chairman of the Indonesian Language Education Program studies S-2 and S-3 since 2009-present.

Ramly was born in Polewali West Sulawesi. He is the eldest son of seven brothers and sisters from the marriage of Hasan, S. father and Sitti Najmiah mother. His educations are elementary graduate in 1971; Junior High School, Mambi in 1974; Teacher High School in Polewali in 1997; University graduate majoring in Indonesian Education-Literature and Local Language in 1984; Magister in the field of Linguistics at Padjadjaran Bandung graduated in 2008. Later, he continued his study majoring in Indonesian Education S3.

In 1985, he was appointed as assistance lecturer at IKIP Ujung Pandang. Since 1986, he became a lecturer at the same institution and now entitled for Lektor Kepala IV/C. Educational activities done such as a writing book entitled Bahasa Indonesia untuk Mata Kuliah Pengembangan Kepribadian published by UNM; being assessor of Indonesian teachers supervised by State University of Makassar; attending Training of Trainers (TOT) for teaching practice guide in Bogor in 1999 and also be guided for Lecturer and Teacher at UNM from 1999-2004; reviewer in the Decentralized Basic Education activities USAID South-Sulawesi in 2006; a member of Monitoring and Evaluation the effectiveness of Learning Model and Management for qualified school in South-Sulawesi; attending International activities, such as presenting a paper in Sandwich-Like program in Ohio State University-US (October 2011January 2012), and many others.

Besides, academic activities ever done are presenting a paper entitled "Language in South and East Sulawesi”. In Malaysia 2000; Indonesia-Malaysia cultural symposium in Bandung 1993; a guide in action research training in Bone (2011), Soppeng (2006), Mamasa (2008), Majene and Polmas (2015); presenter at International symposium of a paper entitled at tourism schools in South Sulawesi in 2014; conducting a research entitled developing a model of Indonesian Learning Materials for Tourism School in 2013 , and many others. 